\section{Hygienic-sanitary evaluation of sushi and sashimi sold in Messina and Catania, Italy}

\author{
Daniele Muscolino, Filippo Giarratana, \\ Chiara Beninati, Agata Tornambene, \\ Antonio Panebianco, Graziella Ziino \\ Dipartimento di Scienze Veterinarie, \\ Università degli Studi di Messina, Italy
}

\section{Abstract}

Sushi and sashimi are traditional Japanese food, mostly consisting of raw seafood alone or in combination with rice. Eating sushi and sashimi has become popular in many countries even outside Japan. This food is not free from health risks such as ingestion of pathogenic bacteria or parasite. The aim of this study was to investigate on hygienic-sanitary quality of sushi and sashimi sold in the cities of Messina and Catania, Southern Italy. Fifty samples (38 sushi and 12 sashimi) were analysed to determinate the aerobic mesophilic bacteria (AMB), psycrophilic bacteria $(\mathrm{PB})$, Enterobacteriaceae, specific spoilage organisms (SSOs), Pseudomonas spp., coagulase-positive staphylococci, micrococci, Vibrio spp., Bacillus cereus, Salmonella spp. and Listeria monocytogenes. In sushi, AMB ranged from 5.00 to $8.18 \log \mathrm{CFU} / \mathrm{g}$, PB from 4.70 to $7.13 \log \mathrm{CFU} / \mathrm{g}$, Enterobacteriaceae from 1.41 to $6.67 \log \mathrm{CFU} / \mathrm{g}$, while SSOs and Pseudomonas spp. from 3.49 to 7.72 and from 3.36 to $8.00 \mathrm{log}$ $\mathrm{CFU} / \mathrm{g}$, respectively. Micrococci ranged from 3.53 to $5.03 \mathrm{log} \mathrm{CFU} / \mathrm{g}$ and coagulase positive staphylococci were found in 16 samples (2.00 to $3.60 \log \mathrm{CFU} / \mathrm{g})$. Bacillus cereus was found in 3 samples (1.70 to $4.00 \log \mathrm{CFU} / \mathrm{g}$ ), while Vibrio spp. was found in 15 of the sushi samples (1.70 to $3.70 \log \mathrm{CFU} / \mathrm{g}$ ). In sashimi, the $\mathrm{AMB}, \mathrm{PB}$ and SSOs values were higher than $7.00 \log$ CFU/g, Pseudomonas spp. and Enterobacteriaceae were from 6.00 to $8.00 \log$ $\mathrm{CFU} / \mathrm{g}$, while Vibrio spp. were found in six samples with means of $2.00 \log \mathrm{CFU} / \mathrm{g}$. No Salmonella spp. and Listeria monocytogenes were detected in all sushi and sashimi samples.

\section{Introduction}

Sushi and sashimi are traditional Japanese food, though in recent years they attracted a large number of European consumers. Sushi was originally prepared in Southeast Asia as a method to preserve fish. It was formerly used for carps, that were caught, gutted, salted and preserved between two stones, and left to fer- ment for a period ranged from one to three years. Sushi is prepared with cold cooked rice acidified with vinegar, and it is shaped into bite-sized pieces and topped with raw or cooked fish, or formed into a roll with fish, eggs or vegetables, and wrapped in seaweed (nori) (Atanassova et al., 2008).

The sashimi, instead, is characterised by the use of fish and shellfish, which are cut into thin slices and served with several sauces (e.g. wasabi, soy sauce or ponzu sauce), and accompanied with daikon roots (Food and Environmental Hygiene Department HKSAR, 2000).

Sushi and sashimi are ready-to-eat (RTE) food and regarded as a potentially hazardous. Frequently, indeed, foodborne diseases related to sushi e sashimi consumption have been reported (Adams et al., 1994; Atanassova et al., 2008; Barralet et al., 2004; Food and Environmental Hygiene Department HKSAR, 2000; Masotti et al., 2004; Millard and Rockliff, 2003; NSW Food Authority, 2006). Pathogenic bacteria such as Salmonella spp., Staphylococcus aureus, Vibrio parahaemolyticus, Vibrio cholerae, Listeria monocytogenes, Bacillus cereus can occur in materials used for their preparation such as fish, seafood products, vegetables and rice.

In the light of the significant increase of consumption of traditional Japanese foods in Italy and due to the attention of EC Reg. 2073/05 for RTE foods (European Commission, 2005), the aim of this study was to investigate the microbiological quality of sushi and sashimi sold in Messina and Catania (Southern Sicily, Italy).

\section{Materials and Methods}

The study was carried out on 38 samples of sushi and 12 of sashimi collected from restaurants, sushi bar and take-away outlets of Messina and Catania. Different types of sushi were analysed: hosomaki, nigirizushi and uramaki. In addition to rice and nori seaweed, they were made with smoked fish (salmon, tuna and swordfish), canned tuna in oil, surimi, fish eggs, cream cheese, cucumbers, carrots, avocado, sesame or poppy seeds. The sashimi samples were prepared with salmon, tuna or swordfish fillets.

All samples, transported to the laboratory under refrigerated condition, were analysed for the following bacteriological determinations: aerobic mesophilic bacteria (AMB) (ISO 4833:2004; UNI, 2004), psychrophilic bacteria (PB) (ISO 17410:2001; ISO, 2001), specific spoilage organisms (SSOs) (Lyngby Iron Agar at $25^{\circ} \mathrm{C}$ for 5 days), Enterobacteriaceae (IS0 21528-2:2004; ISO, 2004), Pseudomonas spp. (Pseudomonas agar base with CFC supple-
Correspondence: Graziella Ziino, Dipartimento di Scienze Veterinarie, Università degli Studi di Messina, viale Annunziata, 98168 Messina, Italy. Tel. +39.90 .3503761 - Fax: +39.90 .3503937 .

E-mail: gziino@unime.it

Key words: Sushi, Sashimi, Microbiological quality, Food hygiene.

Contributions: the authors contributed equally.

Conflict of interests: the authors declare no potential conflict of interests.

Received for publication: 12 May 2013. Revision received: 27 November 2013. Accepted for publication: 23 January 2014.

This work is licensed under a Creative Commons Attribution 3.0 License (by-nc 3.0)

(C) Copyright D. Muscolino et al., 2014 Licensee PAGEPress, Italy

Italian Journal of Food Safety 2014; 3:1701 doi:10.4081/ijfs.2014.1701

ment at $30^{\circ} \mathrm{C}$ for $48 \mathrm{~h}$ ), quantitative and qualitative determination of Vibrio spp. (Thiosulphate Citrate Bile Salt Sucrose Agar at $37^{\circ} \mathrm{C}$ for $24 \mathrm{~h}$ ), coagulase-positive staphylococci and micrococci (ISO 6888-2:1999; ISO, 1999), Bacillus cereus (IS0 7932:2005; UNI, 2005a), Listeria monocytogenes (ISO 112901:2005 and ISO 11290-2:2005; UNI, 2005b, 2005c) and Salmonella spp. (ISO 6579:2002; ISO, 2002).

Colonies of Enterobacteriaceae, isolated from tuna sashimi, were identified by API $20 \mathrm{E}$ (bioMérieux, Marcy l'Etoile, France). Then, they were cultured on Niven medium, in order to evaluate their istidino-decarboxylase activity. The $\mathrm{pH}$ detection of all samples was made with pH-meter WTW pH330i.

\section{Results}

In sushi samples, the AMB ranged from 5.00 to $8.18 \log \mathrm{CFU} / \mathrm{g}$, and PB from 4.70 to $7.13 \mathrm{log}$ $\mathrm{CFU} / \mathrm{g}$ (Table 1). The Enterobacteriaceae showed a wide range from 1.41 to $6.67 \mathrm{log}$ $\mathrm{CFU} / \mathrm{g}$. The highest percentage of samples for AMB (44.74\%) and PB (47.37\%) were from 6.00 to $7.00 \log \mathrm{CFU} / \mathrm{g}$, while for Enterobacteriaceae (44.74\%) from 4.00 to 5.00 $\log$ CFU/g. Specific spoilage organisms and Pseudomonas spp. ranged from 3.49 to $7.72 \mathrm{log}$ $\mathrm{CFU} / \mathrm{g}$ and from 3.26 to $8.00 \mathrm{log} \mathrm{CFU} / \mathrm{g}$ respectively. Coagulase-positive staphylococci were isolated in 16 samples (42.11\%) with values from 2.00 to $3.60 \log$ CFU/g. Micrococci had values between 3.53 and $5.03 \log$ CFU/g. Bacillus cereus was detected in 3 samples (7.89\%), with 
Table 1. Microbiological results of sushi samples.

\begin{tabular}{|c|c|c|c|c|c|}
\hline \multirow{2}{*}{ Value (log CFU/g) } & \multicolumn{5}{|c|}{ Sushi samples distribution (\%) } \\
\hline & AMB & PB & $\mathrm{SSOs}$ & Pseudomonas spp. & Enterobacteriaceae \\
\hline $1.00<2.00$ & - & - & - & - & $1(2.63)$ \\
\hline $2.00<3.00$ & - & - & - & - & $2(5.26)$ \\
\hline $3.00<4.00$ & - & - & $2(5.26)$ & $2(5.26)$ & $4(10.53)$ \\
\hline $4.00<5.00$ & - & $2(5.26)$ & $1(2.63)$ & $5(13.16)$ & $17(44.74)$ \\
\hline $5.00<6.00$ & $13(34.21)$ & $11(28.95)$ & $16(42.11)$ & $13(34.21)$ & $9(23.68)$ \\
\hline $6.00<7.00$ & $17(44.74)$ & $18(47.37)$ & $11(28.95)$ & $13(34.21)$ & $5(13.16)$ \\
\hline $7.00<8.00$ & 7 (18.42) & 7 (18.42) & $8(21.05)$ & $3(7.90)$ & - \\
\hline$>8.00$ & $1(2.63)$ & - & - & $2(5.26)$ & - \\
\hline
\end{tabular}

CFU, colony forming unit; AMB, aerobic mesophilic bacteria; PB, psychrophilic bacteria; SSOs, specific spoilage organisms.

Table 2. Microbiological results of sashimi samples.

\begin{tabular}{|c|c|c|c|c|c|}
\hline \multirow[t]{2}{*}{ Value $(\log \mathrm{CFU} / \mathrm{g})$} & \multicolumn{5}{|c|}{ Sashimi samples distribution (\%) } \\
\hline & AMB & PB & $\mathrm{SSO}$ & Pseudomonas spp. & Enterobacteriaceae \\
\hline $6.00<7.00$ & - & - & - & $6(50)$ & $6(50)$ \\
\hline $7.00<8.00$ & $7(58.33)$ & $8(66.67)$ & $8(66.67)$ & $6(50)$ & $6(50)$ \\
\hline$>8.00$ & $5(41.67)$ & $4(33.33)$ & $4(33.33)$ & $x^{2}$ & - \\
\hline
\end{tabular}

values between 1.70 and $4.00 \log \mathrm{CFU} / \mathrm{g}$ and Vibrio spp. were observed in 15 samples (39.47\%) ranging from 1.70 to $3.70 \log \mathrm{CFU} / \mathrm{g}$. In all sushi samples, no Salmonella spp. and Listeria monocytogenes were found. The $\mathrm{pH}$ of the rice ranged from 4.6 to 6.6 (mean 5.6), while the $\mathrm{pH}$ of fish from 5.06 to 8.4 (mean $6.06)$.

In sashimi samples, the AMB, PB and SSOs were higher than $7.00 \log \mathrm{CFU} / \mathrm{g}$ (Table 2). The Enterobacteriaceae and Pseudomonas spp. were from 6.00 to $8.00 \mathrm{log}$ CFU/g. Vibrio spp. were observed in 6 samples (50\%) $(\geq 2.00 \mathrm{log}$ $\mathrm{CFU} / \mathrm{g}$ ), while in all 12 samples (100\%) no Salmonella spp. and Listeria monocytogenes were found.

Twenty-five colonies of Enterobacteriaceae, isolated from tuna sashimi, were identified as Citrobacter freundii, Klebsiella oxytoxa, Serratia liquefaciens, Rahnella aquatilis and Raoultella ornithinolytica. All these strains showed istidino-decarboxylase activity on Niven medium. The $\mathrm{pH}$ of sashimi samples examined ranged from 5.86 to 8.4 (mean 6.98).

\section{Discussion}

The microbiological limits for RTE foods such as sushi and sashimi are defined by EC Reg. 2073/2005 (European Commission, 2005). This regulation takes in account two food safety criteria: Salmonella spp. (absence in $25 \mathrm{~g}$ of sample) and Listeria monocytogenes. Sushi and sashimi characterised by shelf-life less than five days are RTE foods unable to support

Table 3. Distribution of results in accordance with international microbiological standards for sushi.

\begin{tabular}{lccc} 
Parameters & Acceptable (\%) & Borderline (\%) & Unsatisfactory (\%) \\
Aerobic mesophilic bacteria & $13(34.21)$ & $17(44.74)$ & $8(21.05)$ \\
Enterobacteriaceae & $1(2.63)$ & $6(15.79)$ & $31(81.58)$ \\
Bacillus cereus & $35(92.10)$ & $3(7.90)$ & - \\
Coagulase-positive staphylococci & $21(55.26)$ & $11(28.95)$ & $6(15.79)$ \\
\hline Salmonella spp. & $38(100)$ & - & - \\
Listeria monocytogenes & $38(100)$ & - & - \\
\hline Vibrio parahaemolyticus & $38(100)$ & - & -
\end{tabular}

the growth of $L$. monocytogenes. For this reason, $L$. monocytogenes must be less than 100 $\mathrm{CFU} / \mathrm{g}$ during the shelf-life of these products.

All samples examined in this study were in accordance with the microbiological criteria of EC Reg. 2073/2005 (European Commission, 2005). On the basis of standards from Gilbert et al. (2000), Hong Kong (Food and Environmental Hygiene Department HKSAR, 2000, 2007) and Food Standards Australia (Food Standards Australia New Zealand, 2001; ANZFA, 2001), 6 sushi samples (21.05\%) examined were considered unsatisfactory for AMB criteria (Table 3). Thirty-one samples (81.58\%) were unsatisfactory for Enterobacteriaceae and 6 (15.79\%) for coagulase-positive staphylococci. Seventeen samples resulted borderline for AMB (44.74\%), 6 for Enterobacteriaceae (15.79\%), 3 for B. cereus (7.90\%) and 11 for coagulase-positive staphylococci (28.95\%), as showed in Table 3.

High bacterial charges as well as potentially pathogen microorganisms were observed in sushi and sashimi examined as previously reported by several authors (Adams et al., 1994; Atanassova et al., 2008; Barralet et al., 2004; Millard and Rockliff, 2003). In this regard, Atanassova et al. (2008) described average AMB values of $6.3 \log \mathrm{CFU} / \mathrm{g}$ in fresh sushi samples. Salmonella spp. and $L$. monocy togenes were found in 1.6 and $1.2 \%$ of samples respectively, while Staphylococcus aureus showed a charge of 2.2 to $4.7 \mathrm{log} \mathrm{CFU} / \mathrm{g}$ (Atanassova et al., 2008). The microbiological status of sushi and sashimi reflects the microbiology of materials used for their preparation. The detection of Vibrio spp. is indeed related to the fish and shellfish products used (Giuffrida and Panebianco, 2008), while B. cereus has been reported in plant foods (especially rice) (Eglezos et al., 2010). Salmonella spp. and $L$. monocytogenes can occur in vegetables and dairy products (cheese), while the finding of $S$. aureus is an evidence of human contact during the preparation of food (Nogara et al., 2004). 


\section{Conclusions}

This study confirms that the production of sushi and sashimi of good quality obviously depends on the choice of raw materials, as also reported by Atanassova et al. (2008) and Millard and Rockliff (2003). A good rice acidification (pH of the rice must be less than 4.6) and the maintaining of cold chain during preparation and storage are also essential to obtain products of good microbiological status. Finally, a proper training of personnel who manipulates this easily perishable food is desirable.

Further bio-molecular investigations will be necessary to confirm the istidino-decarboxylase activity of Enterobacteriaceae strains isolated from tuna sashimi as suggested by Mancusi et al. (2013). The presence of histamine-producing bacteria on sashimi could also represent a potential toxicological hazard.

\section{References}

Adams AM, Leja LL, Jinneman K, Beeh J, Yuen GA, Wekell MM, 1994. Anisakid parasites, Staphylococcus aureus and Bacillus cereus in sushi and sashimi from Seattle area restaurants. J Food Protect 57:311-7.

ANZFA, 2001. Safe food Australia: a guide to the food safety standards. Commonwealth of Australia, Australia New Zealand Food Authority Publ., Canberra, Australia.

Atanassova V, Reich F, Klein G, 2008. Microbiological quality of sushi from sushi bars and retailers. J Food Protect 71:860-4.

Barralet J, Stafford R, Towner C, Smith P, 2004. Outbreak of Salmonella Singapore associated with eating sushi. Available from: http://www.health.gov.au/internet/main/pu blishing.nsf/C ontent/cda-2004cdi2804p.htm

Eglezos S, Huang B, Dykes GA, Fegan N, 2010. The prevalence and concentration of Bacillus cereus in retail food products in Brisbane, Australia. Foodborne Pathog Dis 7:867-70.

European Commission, 2005. Regulation of 15 November 2005 on microbiological criteria for foodstuffs, 2073/2005/EC. In: Official Journal, L 338/1, 22/12/2005.

Food and Environmental Hygiene Department
HKSAR, 2000. Risk assessment studies report No. 2. Microbiological hazards evaluation. Sushi and sashimi in Hong Kong. Available from: http://www.cfs.gov.hk/english/programme/programme_haccp/files/s s_ras2_eng.pdf

Food and Environmental Hygiene Department HKSAR, 2007. Microbiological guidelines for ready-to-eat food. Available at: http://www.cfs.gov.hk/english/whatsnew/w hatsnew_act/files/MBGL_RTE\%20food_e.p df

Food Standards Australia New Zealand, 2001. Guidelines for the microbiological examination of ready-to-eat foods. Available from: http://www.foodstandards. gov.au /publications/documents/Guidelines $\% 20 \mathrm{fo}$ r\%20Micro\%20exam.pdf

Gilbert RJ, de Louvois J, Donovan T, Little C, Nye K, Ribeiro CD, Richards J, Roberts D, Bolton FJ, 2000. Guidelines for the microbiological quality of some ready-to-eat foods sampled at the point of sale. Available from: http://webarchive.nationalarchives.gov.uk/+/http://www.hpa.org.uk/ cdph/issues/CDPHVol3/no3/guides_micro. pdf

Giuffrida A, Panebianco A, 2008. [Igiene e tecnologie dei prodotti della pesca freschi e trasformati]. In: Colavita G, ed. [Igiene e tecnologia dei prodotti di origine animale]. [Book in Italian]. Le Point Vétérinarie Italie ed., Milano, pp 274-6.

ISO, 1999. Microbiology of food and animal feeding stuffs. Horizontal method for the enumeration of coagulase-positive staphylococci (Staphylococcus aureus and other species). Part 2: technique using rabbit plasma fibrinogen agar medium. ISO Norm 6888-2:1999. International Standardization Organization ed., Geneva, Switzerland.

ISO, 2001. Microbiology of food and animal feeding stuffs. Horizontal method for the enumeration of psychrotrophic microorganisms. ISO Norm 17410:2001. International Standardization Organization ed., Geneva, Switzerland.

ISO, 2002. Microbiology of food and animal feeding stuffs. Horizontal method for the detection of Salmonella spp. ISO Norm 6579:2002. International Standardization Organization ed., Geneva, Switzerland.

ISO, 2004. Microbiology of food and animal feeding stuffs. Horizontal methods for the detection and enumeration of
Enterobacteriaceae. Part 2: colony-count method. ISO Norm 21528-2:2004. International Standardization Organization ed., Geneva, Switzerland.

Mancusi R, Bini RM, Cecchini M, Delle Donne G, Rosmini R, Trevisani M, 2013. Occurance of histamine in fih products on markets. Ital J Food Safety 1:35-9.

Masotti G, Amadei P, Lanni L, 2004. [Pesce crudo. Condizioni igieniche, operative e strutturali nei ristoranti giapponesi]. [Article in Italian]. Available from: http://www.sivemp.it/userfiles/_documents__rivista_/26_58_62_pesce.pdf

Millard G, Rockliff S, 2003. Microbiological quality of sushi. Available from: http://www.health.act.gov.au/c/health?a=d a\&did=10060511\&pid=1094601516

Nogara M, Rossari C, Stella S, Cozzi M, Cantoni C, 2004. [Valutazione microbiologica del pesce crudo utilizzato per la preparazione del sushi]. [Article in Italian]. Pesce 5:121.

NSW Food Authority, 2006. Temperature control of sushi. A technical report on predicting microbial growth in sushi stored at various temperature. New South Wales Food Authority ed., Silverwater, Australia.

UNI, 2004. [Microbiologia di alimenti e mangimi per animali. Metodo orizzontale per la conta di microrganismi. Tecnica della conta delle colonie a $30^{\circ} \mathrm{C}$ ]. [Regulation in Italian]. UNI Norm 4833:2004. Italian Unification Institute ed., Milan, Italy.

UNI, 2005a. [Microbiologia di alimenti e mangimi per animali. Metodo orizzontale per la conta di Bacillus cereus presunto. Tecnica della conta delle colonie a $30^{\circ} \mathrm{C}$ ]. [Regulation in Italian]. UNI Norm 7932:2005. Italian Unification Institute ed., Milan, Italy.

UNI, 2005b. [Microbiologia di alimenti e mangimi per animali. Metodo orizzontale per la ricerca e la conta di Listeria monocytogenes. Parte 1: metodo per la ricerca]. [Regulation in Italian]. UNI Norm 112901:2005. Italian Unification Institute ed., Milan, Italy.

UNI, 2005c. [Microbiologia di alimenti e mangimi per animali. Metodo orizzontale per la ricerca e la conta di Listeria monocytogenes. Parte 2: metodo per la conta]. [Regulation in Italian]. UNI Norm 112902:2005. Italian Unification Institute ed., Milan, Italy. 